\title{
Extraction of lineaments and faults using gravity second horizontal derivative data obtained using Fourier transform
}

\author{
E. E. Epuh ${ }^{1}$, E. O. Joshua ${ }^{2}, 2018$ \\ ${ }^{1}$ Department of Surveying and Geoinformatics, University of Lagos, Nigeria \\ ${ }^{2}$ Department of Physics, University of Ibadan, Nigeria \\ Received 16 May 2018
}

\begin{abstract}
Лінійні аномалії важливі Аля інтерпретащії гравітащійних даних, оскільки вони є індикаторами Аеяких важливих структурних особливостей. Круті градієнти горизонтаяьних похіАних гравітаційного поля зазвичай відображають лінеаменти і розломи або зміни склауу, що Аає змогу описувати структурні тенденції регіону. Це досліАження спрямоване на з'ясування структурного тренду басейну Гонгола і грунтується на конволюції яАра Фур'є Аругої горизонтальної похіАної (АГП) усіченої моделі горизонтального пару і аномалії гравітащійного поля. ЯАро Фур'є АГП отримано перетворенням Фур'є аномахії Буге плоского пару з експоненційною зміною контрасту густини. Розподіл зваженої густини знайдено за визначенням середнъої глибини безперервної по поверхнях поділу. Грані ідентифіковано замкнутим максимумом на карті АГП гравітаційного поля. Результати показують, що аномалія Буге $\epsilon$ протяжною негативною аномахією південно-східного - північно-східного простягання, яка відповідає крутозануреній структурі. Ця структура зумовлена гранітною інтрузією піА зоною, обмеженою системами розломів, що чітко простежується на мапі залишкових ізостатичних аномалій. Горизонтальні градієнти аномалій гравітапійного поля в редукщії Буте басейну Аали змогу Ауже чітко виявити грані, лінеаменти і розломні структури. Головні і підпорядковані лінеаменти, отримані при аналізі карти АГП, нанесено на карту залишкової ізостатичної аномалії гравітаційного поля, в результаті пого створено структурну карту АосліАжуваного району. Аінеаменти 3 простяганням північний схіА - південний схіА і схіА - захіА інтерпретовано як системи розломів зі зміщенням по вертикальній площині. Круті градієнти є відображенням різких меж або поділів між блоками фундаменту з контрастними властивостями, такими як розлом, зона зсуву фундаменту і контакт интрузий. Тектонічну інформацію, отриману за розподіяом лінеаментів, підтверджено 2D гравітаційною модемю басейну. Використання цих моделей і карти розломів сприятимуть вибору перспективних районів для детального картування покладів вуглеводнів.

Ключові слова: Аруга горизонтальна похідна, перетворення Фур'є, аномахія Буге, лінеаменти, розломи.
\end{abstract}

Introduction. Taking the horizontal derivatives of the Bouguer anomaly emphasizes changes in the horizontal gradient. This is effectively another way of removing (or suppressing) the regional trends in the gravity data. Edge enhancement in potential field data helps geologic interpretation. It not only depicts changes in lithology, but also provides the information on structural systems and deformation styles [Zhang et al., 2011]. Over the last few years, increasing interest has been expressed for using the gravity gradi- ent interpretation due to more sensitivity of gravity gradient to geologic structure than gravity itself [Aydogan, 2011]. The gravity measurement can be directly transformed to horizontal gravity gradient. Klingele et al., [1991] discussed the application of horizontal derivatives to gravity gravimetric data. The position of gravity anomalies horizontal gradient maxima was presented by Cordell and Grauch [1985] as a method to locate abrupt changes in density of subsurface rocks. The establishment of high priority regions for de- 
tailed exploration requires the determination of lineaments and faults using gravity second horizontal derivatives. Boschetti [2005] proposed different edge-detection algorithms based on the use of horizontal or vertical gradients of potential-field anomalies. These are used in the visual interpretation of both gravity and magnetic maps in order to detect the main geological structures. Several edge-detection algorithms can be found in the literature, all of which are based on image gradients [Aydogan, 2011]. These gradients are calculated from the image itself, rather than measured. Edge detection neither generates new information, nor extracts information from geophysical maps. Boschetti, [2005] opined that edge detection only transforms such information. Via edge detection, the information which is contained within the entire image pixel set is displayed in a form that helps the user to focus on the main features of a map and to interpret them in terms of geological structures [Aydogan, 2007; Hornby et al., 1999]. Works on edge detection were adopted by various authors [Blakely, Simpson, 1986; McGrath, 1991; Mallat, Zhong, 1992; Moreau et al., 1997; Boschetti et al, 2001; Trompat et al., 2003; Cooper, Cowan, 2006; Aydogan, 2011]. Several authors developed various methods based on the use of horizontal, or vertical, gradients of potential-field anomalies [Rao et al., 1981; Grauch, Cordell, 1987; Reid et al., 1990; Marcotte et al., 1992; Roest et al., 1992; Zeng et al., 1994; Hsu et al., 1996; Fedi, Florio, 2001]. Potential-field data correspond to the superposition of effects from all causative sources. This superposition is the major problem in the interpretation of potential field data since it possesses an inverse problem which has no unique solution. Canny [1986] introduced some analytic expressions for the criteria that have to be optimized in edge detection. In the case of a low noise level, gradient estimations are the classical methods which give satisfactory results. Lunscher [1983], Modestino and Fries [1977], and Shanmugam et al. [1979] developed different edge-detection operators by associating low-pass filtering with the gradient detector. Shen and Castan [1986] pro- posed an algorithm based on a recursive form with exponential impulse response to detect step edge using a second horizontal derivative filter. The edges of the anomalous mass come in many forms and shapes. They might be in the form of lineaments and faults and density contrast showing various structural boundaries. The gradient extreme of anomalies usually corresponds to the boundaries of the existence of these anomalies and were used to approximate edges of source bodies or to analyze lineaments [Blakely, Simpson, 1986].

This paper suggests a method for our edge operator based on the second horizontal derivative of a truncated horizontal-plate model (THPM) model for the delineation of lineaments and faults in the Gongola basin. In this research, a cross correlation function was established between the two-dimensional step model and density distribution as applied to the truncated horizontal plate model (THPM) using the concept of Fourier transform as applied on the potential data. The objective of this approach is testing its viability in the detection of deep faults in the presence of near surface features. In this study, the THM model is considered in terms of density varying exponentially with depth. A Fourier transform of the observed gravity data is carried out to determine the Fourier Kernel which corresponds to the edge detector with respect to the wave number and the shot point distance.

Description of the study area and Geology of the basin. Description of the study area. The study area is located North-West of the upper Benue Trough in the Gongola basin. It is bounded by Longitudes $10.3^{\circ} \mathrm{E}$ and $10.8^{\circ} \mathrm{E}$, Latitudes $9.9^{\circ} \mathrm{N}$ and $11.1^{\circ} \mathrm{N}$. The Cartesian coordinates are defined in Easting as $625000 \mathrm{mE}$ and $700000 \mathrm{mE}$ and in Northings as $1096818 \mathrm{mE}$ and $1225000 \mathrm{mN}$ respectively. The study area is located among the following places: Alkaleri(W), Darazo (NW), Dukku (NE), Larishi (E), and Kwala (S).

Geology of the basin. The Benue Trough is one of the most important rift features in Africa and is believed to be formed by the rifting of the central West African basement during the Cretaceous. The trough is subdivided into 
Lower, Middle and Upper Benue (Fig. 1, a) with its Southern limit towards the northern boundary of Niger Delta and its northern sector include the easterly Yola/Garoua Flank extending across the Cameroon border and the northerly Gongola Flank. Careful re-examination of geophysical evidence makes it quite clear that there are only three interconnected rifts in West Africa; the Lower Benue Rift which extends from the Gulf of Guinea to a triple junction near Chum and the Gongola and Yola Rifts which extend to the north and east, respectively from the Chum triple junction. These three rifts opened during the earlier part of the Mesozoic and were subsequently filled with Cretaceous sediments [Freeth, 1984]. The trough is about $700 \mathrm{~km}$ long and $100-150 \mathrm{~km}$ wide. The trough development is attributed to major horizontal movements along a series NE-SW trending fractures accompanied by basement fragmentation, subsidence and rifting during Early Cretaceous opening of the South Atlantic Ocean [Grant, 1971; Akande et al., 1998]. The Gongola basin of the upper Benue Trough is a North-South trending arm of the $1000 \mathrm{~km}$ long Benue Trough. These sub basins contain thick sediment accumulations (mainly Cretaceous) in excess of $5 \mathrm{~km}$ deposited under varying environments. The sediments have been subjected to main tectonic phases which account for the observed folding, faulting and fracturing of the rocks (Fig. 1, b). These tectonic episodes were dominant in the NE-SW direction. Further discussion on the structurization of the basin are found in [Avbovbo, 1986; Benkhelil, 1989; Fairhead, Binks, 1991]. According to Benkhelil [1989], the evolution of the basin is also as a result of stress and strain resulting in deformation or faulting through a wrench process.

The Upper Benue Trough (see Fig. 1, a) of Nigeria is comprised of three basins: the east-west trending Yola Basin (Yola Arm), the north-south trending Gongola Basin (Gongola Arm) and the northeast-southwest trending Lau Basin (Main Arm). These sub basins contain thick Cretaceous sediments with thickness ranging between $5 \mathrm{~km}$ (SE) and $7 \mathrm{~km}$ (NE). Tectonic activities such as folding, faulting and fracturing has greatly affected the deposited sediments (see Fig. 1, b). The characteristics of the main stratigraphic formations in the Gongola basin: KerriKerri, Gombe, Pindiga, Yolde and Bima (see Fig. $1, b$ ) are fully discussed in various literature: [Carter et al., 1963; Ofodile, 1976; Petters, 1982; Petters, Ekweozor, 1982; Avbovbo et al., 1986; Obaje, 1994; Olugbemiro et al., 1997; Obaje et al., 2006; Obaje, 2009]. According to [Okiwelu et al, 2015], the Benue Trough is filled with sediments of Cretaceous (Albian-Maastrichtian) age which are made up of sandstones, shales/clay, limestone, mudstone (mainly marine in character) and underlain by Precambrian basement. The three main tectonic evolutions which determined the stratigraphic succession of the basin as suggested by [Petters, 1978] include the Bima formation which corresponds to the rift sequence which comprises sediments deposited within the graben and horst structures during the Albian-Cenomanian sedimentation.

Data Acquisition. The gravity readings were obtained using the La Coste Model G No. 572 gravimeter. Gravimeter readings changed (drift) with time as a result of elastic creep in the springs, producing an apparent change in gravity at a given station. The instrument drift is corrected by repeating measurements at the same location at different times of the day. All gravity data acquired at the stations occupied during the survey are reduced relative to the base station. The station interval of $500 \mathrm{~m}$ was used and a total of 1813 gravity stations were observed.

Methodology (Second Horizontal Derivative (SHD) Model Formulation using Fourier Transform). In gravity interpretation, the edges come in many forms and shapes. They might be in the form of faults, contacts, and various structural boundaries [Aydogan, 2011]. The gradient extremes of anomalies usually corresponds to the boundaries of the existence of these anomalies and have been used to approximate edges of source bodies or to analyze lineaments [Blakely, Simpson, 1986]. In order to highlight lineaments of gravity data, we make use of a truncated horizontal-plate model (THPM). In this research, the 

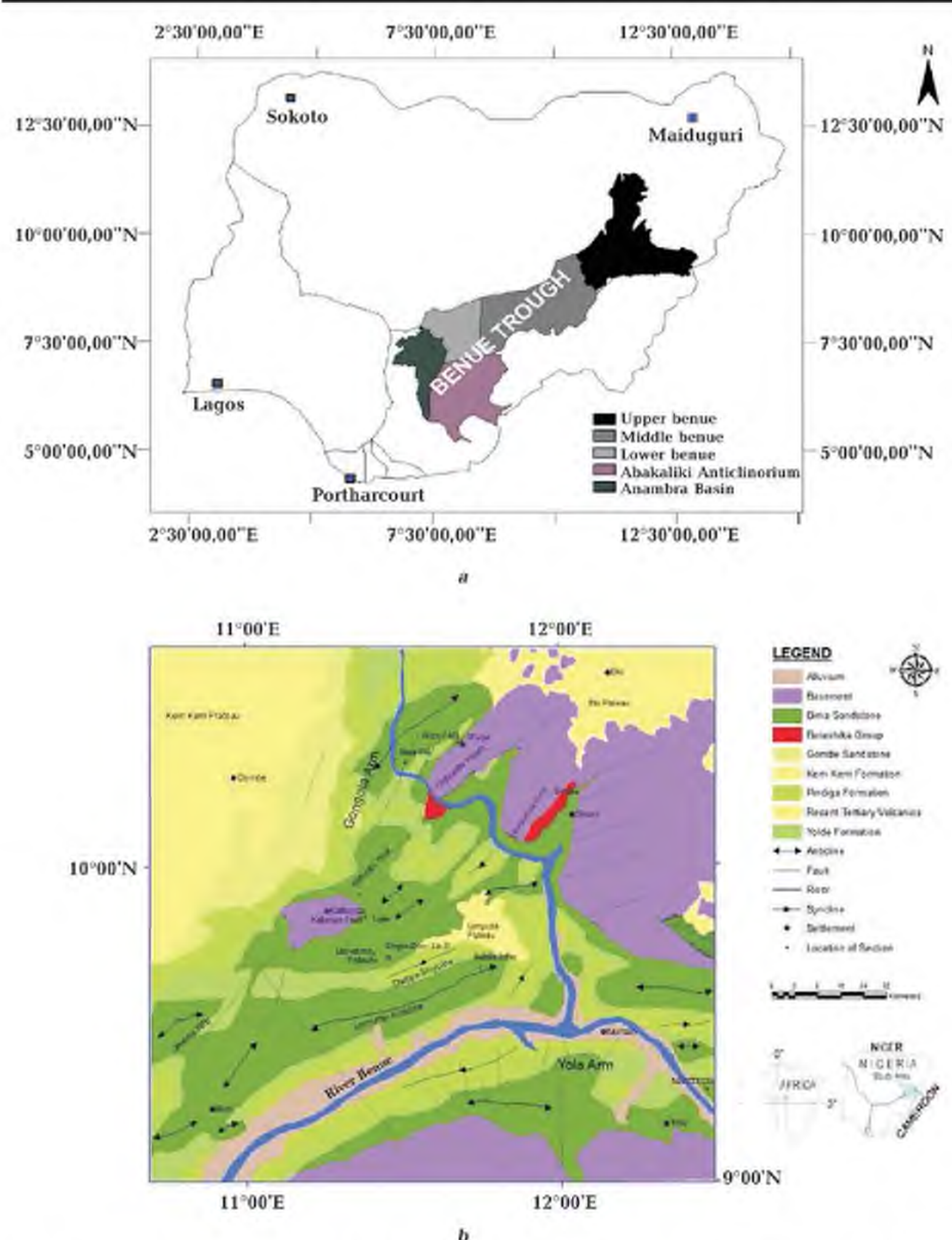

Fig. 1. The map of Nigeria showing the major subdivisions of the Benue Trough [Ologun et al, 2008] (a). Geological map of Upper Benue Trough showing its stratigraphy and Structural trend [Tukur et al., 2015] (b).

horizontal gradient method was used to locate density boundaries from the gravity data. The horizontal gradients were estimated from the convolution kernel referred to as gradient operator. The first step in the determination of the gradient operator is the estimation of the 
derivatives in the $x$ - and $y$-directions in order to smooth the image. Fourier transform utilizes the frequency domain in its operation. In the frequency domain, a convolution is established by multiplying the Fourier transform of the given function obtained as a Fourier kernel with the observed gravity. Using the properties of the convolution process Aydogan [2011] showed that the gradient operator is obtained as follows:

$$
M_{s}=\frac{\partial}{\partial x}(F g)=\frac{\partial}{\partial x}(F) g,
$$

$$
M_{y}=\frac{\partial}{\partial y}(F g)=\frac{\partial}{\partial y}(F) g .
$$

The magnitude of the gradient is given by [Aydogan, 2011]:

$$
M=\sqrt{M_{x}^{2}+M_{y}^{2}} .
$$

This operation measured the rate of change of field in $\mathrm{x}$ and $\mathrm{y}$ directions and created a resultant grid [Cordell, Grauch, 1985]: The horizontal gradient method used to locate density boundaries from gravity data
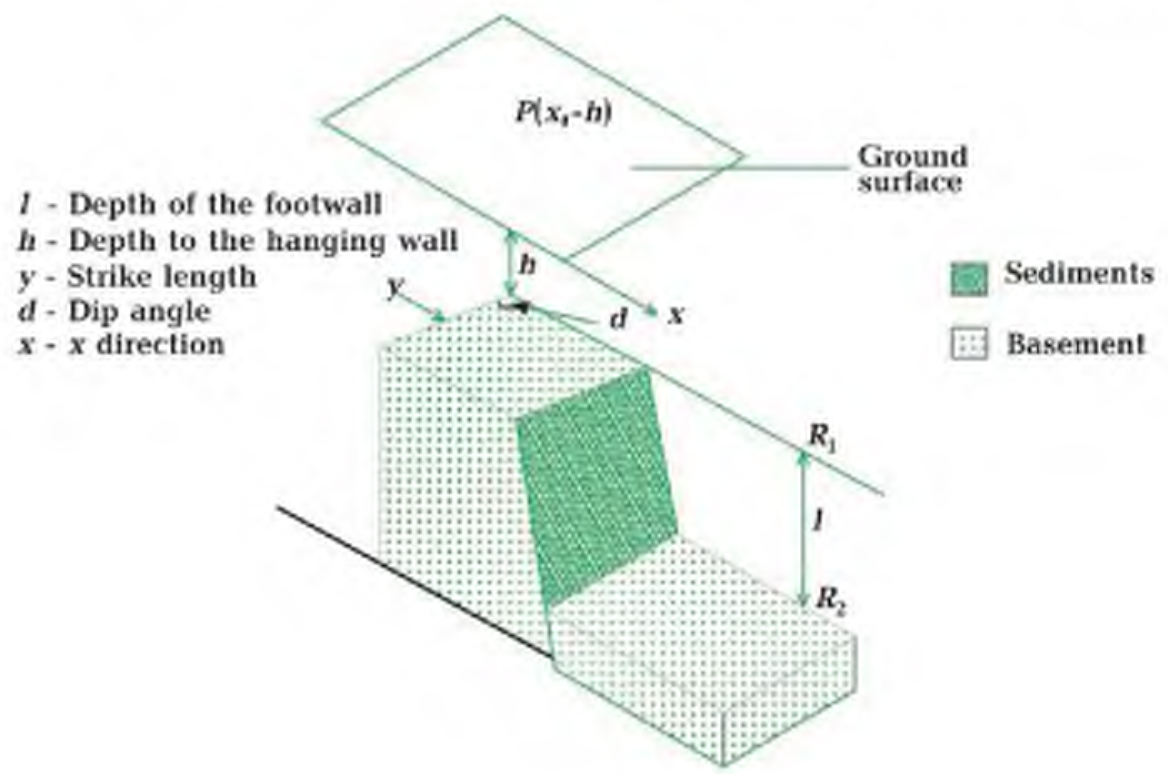

a

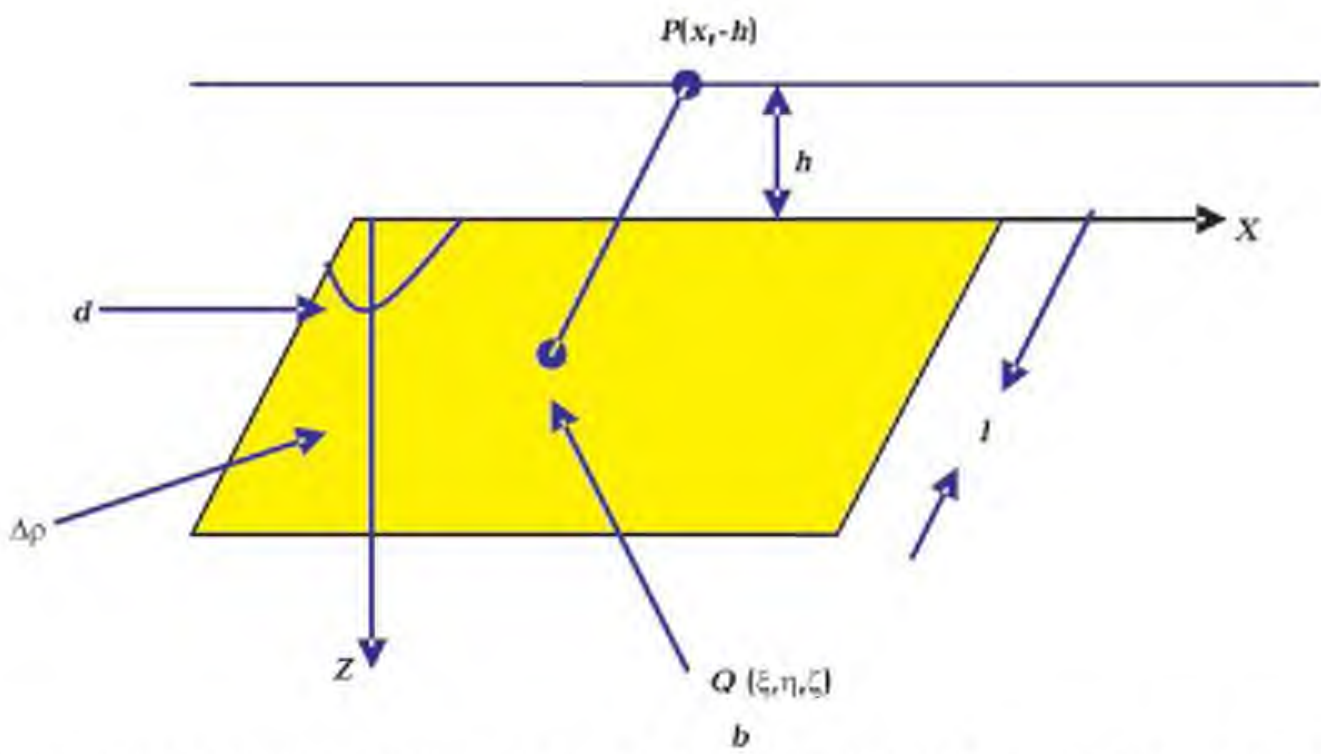

Fig. 2. Geometry of a 2.5D faulted bed (modified from [Chakravarthi, 2008]) (a). Showing the step model approach [Grant, West, 1987] (b). 
[Cordell, Grauch, 1985] is given as:

$$
T H D=\sqrt{\left(\frac{\partial M}{\partial x}\right)^{2}+\left(\frac{\partial M}{\partial y}\right)^{2}} .
$$

Gravity measurements above a sedimentary basin can only detect lateral density contrasts between sediments and basement because usually there is no sufficient density contrast between two sedimentary layers. Fig. 2, $a$ shows how a tectonic fault with a basement off-set detected by gravity displaces vertically the boundary separating the sediments from the basement. The important point is that above point $R_{1}$ and below point $R_{2}$, the fault does not create horizontal density contrasts. The only region where the fault creates a horizontal density contrasts is between point $R_{1}$ and $R_{2}$. As a result, the whole structure shown in Fig. 2, $a$ will produce exactly the same gravity anomaly as the slab model shown in Fig. $2, b$. The anomalous material in this case has the form of a flat step which goes to infinity in the positive direction of $\mathrm{x}$ and is assumed to have a uniform density contrast throughout its entire bulk. Since most faults have a strike length that is many times their throw, the step is assumed to be two-dimensional.

Consider a material to be distributed with a surface density $r(x, y) \mathrm{g} / \mathrm{cm}^{3}$ of the horizontal plane $z=0$. To calculate the gravitational field of this coating at a point $Q$ in $z=0$, a set of circular cylindrical coordinates $(r, \varphi, z)$ is chosen, whose axis is vertical and whose origin is placed at $Q$ as shown in Fig. 3. At a point $\mathrm{P}$ on the axis, gravitational potential will be [Grant, West, 1987]:

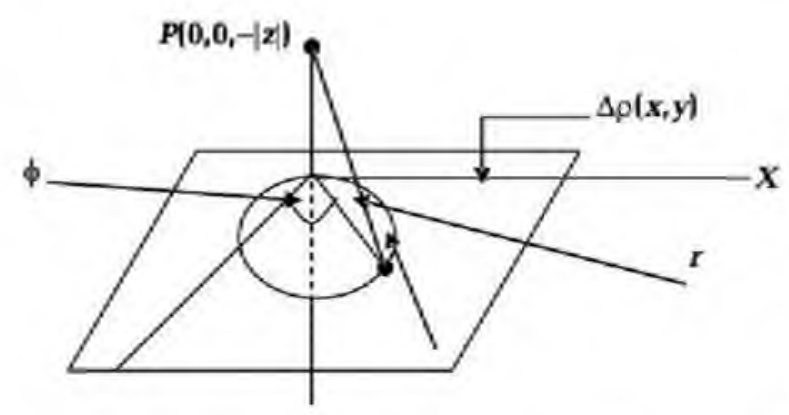

Fig. 3. The *equivalent Stratum» [Grant, West, 1987].

$$
U_{p}=-G \int_{0}^{\infty} \int_{0}^{2 \pi} \frac{\rho(r, \varphi)}{\sqrt{r^{2}+z^{2}}} r d \phi d r,
$$

where $\rho$ - surface density, $U p$ - gravitational potential at $\mathrm{P}, r$ - radius, $z$ - horizontal plane.

Gravitational field at $P$ is given as:

$$
\mathbf{P}=-\nabla U_{p} .
$$

Since the potential $U$ is due to masses that are locally distributed on $z=0$, the gravity effect at $P$ is written as:

$$
\begin{gathered}
\Delta g_{p}=-\frac{\partial U_{p}}{\partial z}= \\
=G|z| \int_{0}^{2 \pi} \frac{\rho(r, \varphi)}{\left(r^{2}+z^{2}\right)^{3 / 2}} d \varphi d r, z<0 .
\end{gathered}
$$

The negative sign being used because $\Delta g$ is to be measured in the direction of $g$. It is required to evaluate the integral in the limit as $z=0$ by utilizing a small circle at $Q$ of radius $r$ which is finite. The radius $r$ is chosen such that throughout the circle $r(x, y)$ does not change appreciable from its value at $Q$. This gives [Grant, West, 1987]:

$$
\begin{gathered}
\Delta g_{p}=G \rho(Q)|z| \int_{0}^{\infty} \int_{0}^{2 \pi} \frac{r d \varphi d r}{\left(r^{2}+z^{2}\right)^{3 / 2}}= \\
\quad=2 \pi G \rho(Q)\left(1-\frac{|z|}{\sqrt{\left(r^{2}+z^{2}\right)}}\right) .
\end{gathered}
$$

This finally gives

$$
\Delta g(Q)=2 \pi G \rho(Q) .
$$

But the position of $Q$ in $z=0$ is arbitrary, so that we may write:

$$
\Delta g(x, y)=2 \pi G \rho(x, y) .
$$

Suppose that the gravity effect $D g(x, y)$ on $z=0$ is produced by an unknown distribution of matter below this plane. Then whatever the array of masses may actually be, its effect at any point in $z=0$ would be exactly the same if it were replaced by the surface distribution on $z=0$ given by equation $6 \mathrm{~d}$. This density coating is therefore called the equivalent stratum for the unknown distribution of matter in $z>0$.

From Eq. 6d, the formula for the profile of 
gravity effect across the step modified from Grant and West [1987] is given as follows

$$
\Delta g(x)=2 \pi G \Delta \rho x
$$

$$
\times\left\{\begin{array}{l}
\frac{\pi}{2}+(z) \tan ^{-1} \frac{x-\cot d}{z}-\tan ^{-1} \frac{x}{h}+ \\
\left(x \sin ^{2} d+h \sin d \cos d\right) \ln \left[\frac{(x-\cot d)^{2}+(z)^{2}}{x^{2}+h^{2}}\right]^{1 / 2} \\
-\left(x \sin d \cos d+h \cos ^{2} d\right)\left(\tan ^{-1} \frac{x-\cot d}{z}-\tan ^{-1} \frac{x}{h}\right)
\end{array}\right\}
$$

By putting $z=1+h-$ depth to basement. We may write the above equation as:

$$
\Delta g(x)=2 \pi G \Delta \rho f(x, z, d) .
$$

The first and second horizontal derivatives $\left(\Delta g_{x}, \Delta g_{x x}\right)$ of the above expression in Eq. 7a produce an implicit function. The object is to find a single function that best approximates the function $f(x, z, d)$ with respect to density.

In the second horizontal derivative of the truncated horizontal-plate model equation (Eq. 4), a uniform density contrast is assumed which is in consonance with the step model concept and characteristics utilized in this study as shown in Fig. 2, b. In this study also, the density of the sedimentary structure is considered to varying exponentially with depth with respect to Eq. 7b. According to Cordell [1973]

$$
\Delta \rho f(x, z, d)=\rho_{0} e^{-\gamma z},
$$

$\gamma$ is defined as attenuation which is a function of the horizontal derivative $(x)$ with respect to the lateral density variation and the dip angle $d$ of the anomalous mass.

Cordell [1973] also showed that the thickness of the Bouguer slab with exponential density contrast variation is given as:

$$
z=\frac{-1}{\gamma} \log \left[1-\frac{\gamma \Delta g}{2 \pi G \rho_{0}}\right],
$$

where $\gamma$ - attenuation. From Eq. $9 \Delta g$ is obtained as

$$
\Delta g=\frac{2 \pi G \rho_{0}}{\gamma}\left[1-e^{-\gamma}\right] .
$$

The Fourier transform of an aperiodic function is given as

$$
F(k)=\int_{-\infty}^{\infty} f(x) e^{-i k x} d x
$$

$F(k)$ - Fourier transform in the wavenumber domain, $k$ - wavenumber and is given by

$$
F[\Delta g(k)]=\frac{2 \pi G \rho_{0}}{k} \int_{-\infty}^{\infty} f\left[1-e^{-k k_{B}}\right] e^{|k| z} d z,
$$

$k$ - wavenumber.

The wavenumber in the Fourier transformed gravity function corresponds to the attenuation constant in the generalized gravity

$$
k=\sqrt{k_{x}^{2}+k_{y}^{2}},
$$

$k_{x}, k_{y}$ - Nyquist wavenumber in the $x, y$ direction $k_{x}=\pi / x_{m}, k_{y}=\pi / y_{m}, k_{x^{\prime}} k_{y}$ - wavenumber, we choose $x$ and $y$ axes which lie in the directions of maximum and minimum horizontal gradient in $\Delta g x_{m}$ and $y_{m}$ - measured distanced between points at which $g_{\text {obs }}$ takes the value $1 / 2 \Delta g$ in these two directions. $\Delta g_{\max }$ - amplitude of the Bouguer anomaly on the surface.

Expanding the exponential and taking into account only the first order term which is a good approximation for the small wavenumber that we are interested in, the above relation for a discrete observation. The Fourier kernel is obtained as

$$
2 \pi G \rho_{0}=\left[1-e^{-k}\right] e^{|k| z}=L_{x y} .
$$

According to Grant and West [1987], the weighting density distribution within a sedimentary structure is given as

$$
r(2 z \sqrt{\gamma})^{-1}=1
$$

where $r=2 \sqrt{\gamma w}, w-k s, s-$ shot point distance, $\gamma$ - attenuation, $z$ - obtained from the above expression as by solving Eq. 15. Using the above parameters, $z$ is obtained as $z=\sqrt{k s}, z-$ mean depth perturbed by the interfaces.

Substituting $z$ in Eq. 15 we obtain

$$
L_{x y}=2 \pi G \rho_{0}\left[1-e^{-k \sqrt{k x}}\right] e^{-k \sqrt{k x}},
$$

where $L_{x y}$ is the edge detector in the $x$ - and $y$-directions. 


$$
\Delta g_{x x}=2 \pi G \rho_{0}\left[1-e^{-k \sqrt{k}}\right] e^{-k \sqrt{k}} \Delta g,
$$

$g_{x x}$ - second horizontal derivative using the Truncated Horizontal Plate Model using the step model (THPSM), $\rho_{0}$ - weathered tertiary density obtained using Parasnis method. The edge is identified by the closed maximum of convolution between these kernels and the gravity data.

Results and Discussion. Second Horizontal Derivative Results. The Bouguer anomaly computed using the crustal density of $2.67 \mathrm{gcc}$ is shown in Fig. 4. The map revealed a largescale negative Bouguer anomaly trending

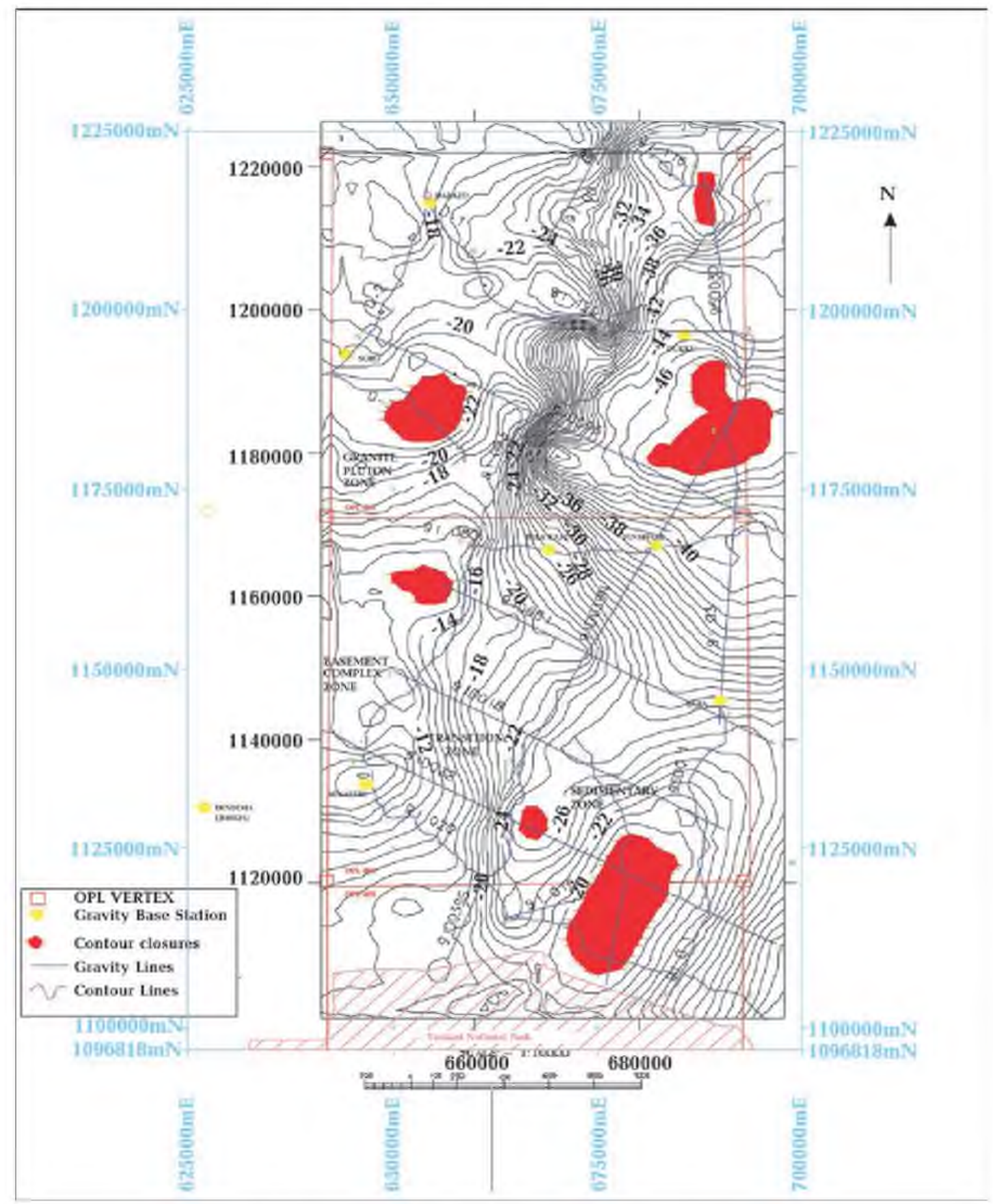

Fig. 4. Bouguer gravity anomaly map (density 2.67 ). 
SW-NE to E-W over the central part of the area. Closer geological and structural observation of this anomaly's axes suggested that its general trend followed an inferred granite intrusion area. The quite different nature of the Bouguer gravity map on the northern side was marked by gravity lows, bounded by rela- tively steep gradients occurring over or near higher metamorphic formations and other granitic plutons, suggesting the existence of a suture zone between two of the crust's block

The results of the second horizontal gradient of the gravity are shown in Fig. 5. The gradient extremes of anomalies usually cor-

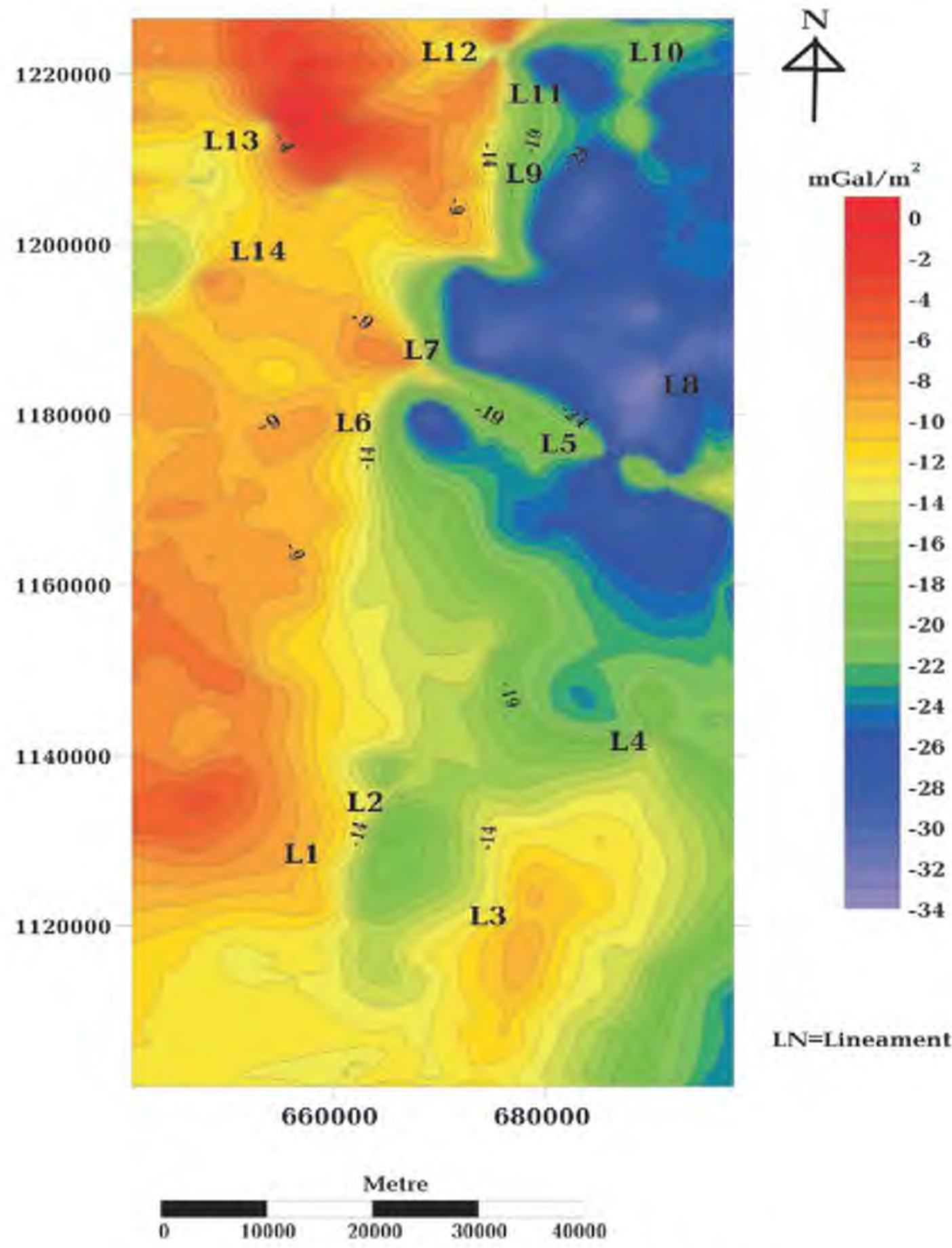

Fig. 5. Second horizontal derivative $\operatorname{map}\left(\mathrm{C} . \mathrm{I}=1 \mathrm{mGal} / \mathrm{m}^{2}\right.$ ). 
responds to the boundaries of the existence of these anomalies and have been used to approximate edges of source bodies or to analyze lineaments [Blakely, Simpson, 1986]. The edges of the structures were clearly defined in the SHD map using the colour separation obtained in the map. The density boundar- ies of the various zones within the study area were also defined. Local minima of the gradient magnitude were used to determine lineaments in the derivative gravity anomaly map. Zeng et al. [1994] opined in his work that major faults can be inferred from gradient zones on gravity-anomaly maps as first-order

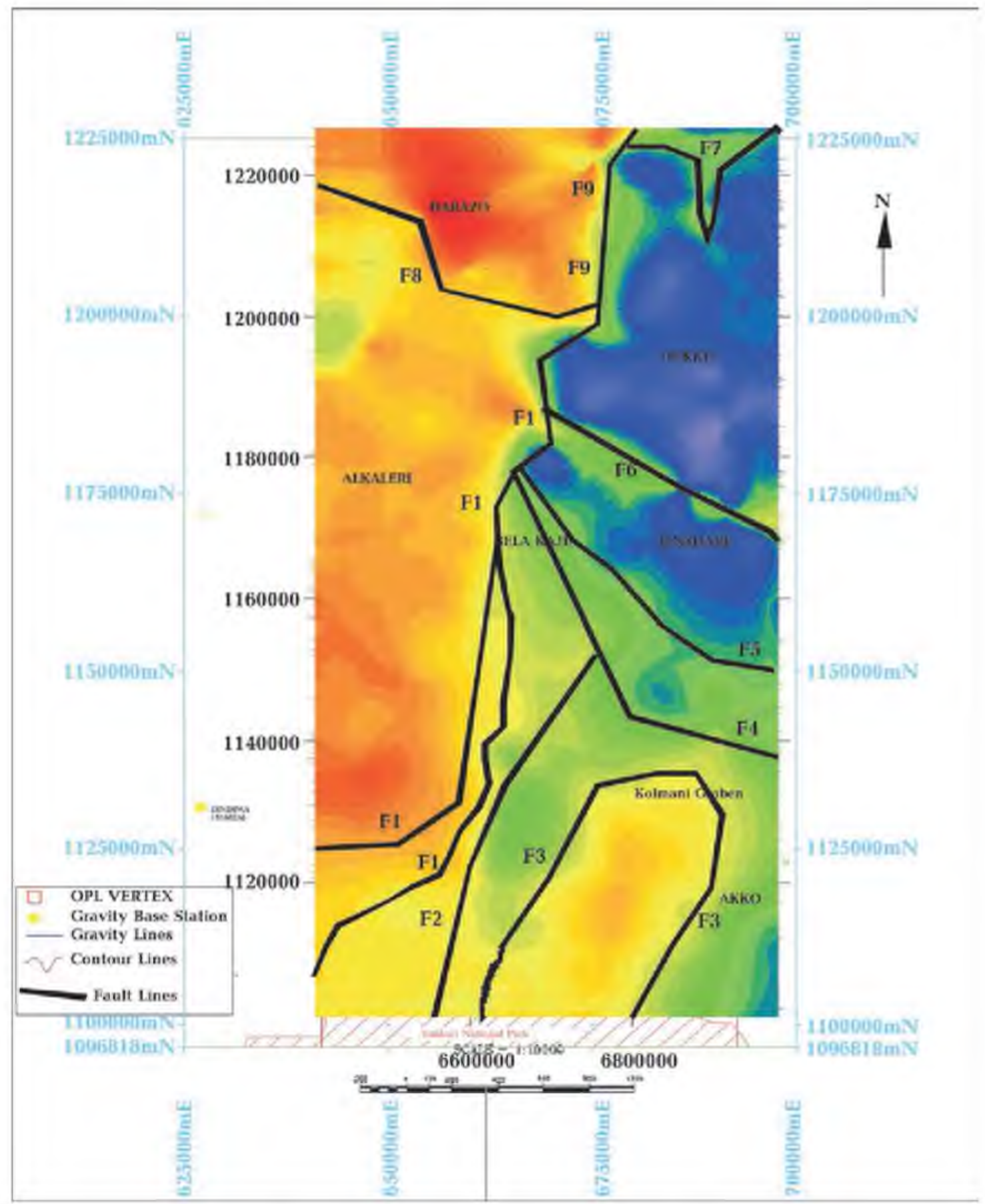

Fig. 6. SHD overlaid on a gravity base map. 


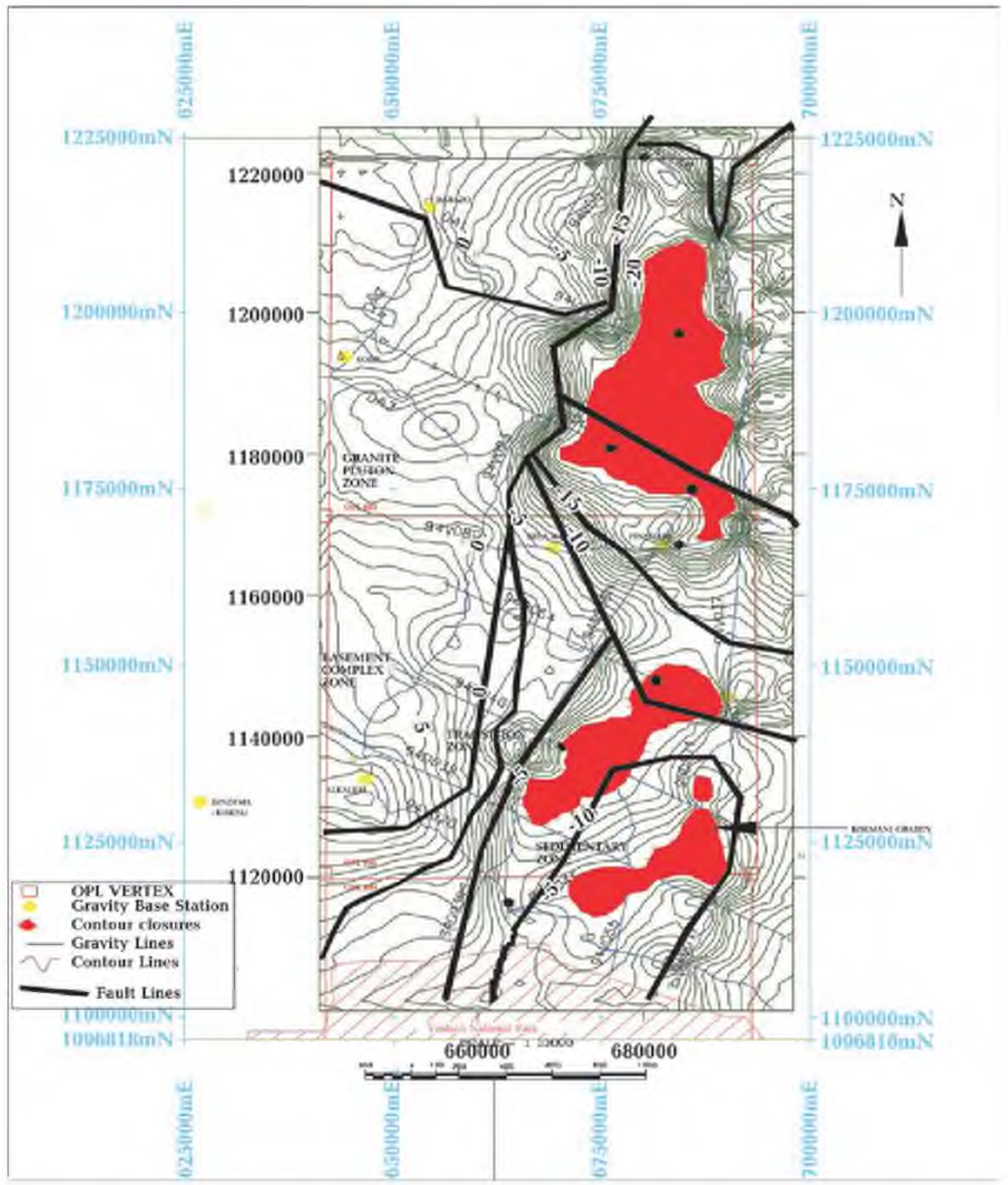

Fig. 7. Lineaments/faults obtained from SHD map superimposed on AH residual anomaly map.

faults. Several lineaments were traced from the linear trends found on the derivative map beyond the edge of the anomalous mass. The lineaments range from $\mathrm{L}_{1}$ to $\mathrm{L}_{14}$ as shown in Fig. 5. In defining the location of linear features, faults were traced easily along these salient lineament features which showed the trend of deep and minor faults.
In order to define the fault locations on the base map, the lineament/fault map was overlaid over the base map as shown in Fig. 6 and over the isostatic residual map as shown in Fig. 7. This is meant to correlate the defined edges of structures, lithologic contacts and faults on the SHD/isostatic residual anomaly map with the modelled residual anomaly 
profiles to determine if the tectonic features exhibited in both maps and models corroborate. In the study area, 9 faults were identified after merging 14 lineaments into single faults. Fig. 6 shows fault maps superimposed on the residual gravity anomaly map. Most of the geological features can be visually shown to fit in with our results. According to the defined fault systems of the basin, the $\mathrm{L}_{1}$ lineament which appeared in the Bouguer gravity anomaly map as a gradient zone geologically belong to one fault system $\left(F_{1}\right)$ as shown in Fig. 5 . The $\mathrm{L}_{1} \rightarrow \mathrm{L}_{6} \rightarrow \mathrm{L}_{7}$ lineaments were considered to be one fault system $\left(\mathrm{F}_{1}\right)$ after they are combined. This fault is consistent with the NE-SW trending fault which was also reported by Osazuwa et al., [1981] and Fairhead et al., [2013]. The fault system $\left(\mathrm{F}_{2}\right)$ is obtained by combining the $\mathrm{L}_{2} \rightarrow \mathrm{L}_{6}$ lineaments and is compatible with the buried fault system extending in the SW-NE direction of Alkaleri. It could be said that the $\mathrm{L}_{3} \rightarrow \mathrm{L}_{4}$ lineaments coincide with the normal fault $\left(\mathrm{F}_{3}\right)$ located at the SE side of Kolmani (Akko sub basin). This fault is also supported by combining the $\mathrm{L}_{4} \rightarrow \mathrm{L}_{6}$ lineaments which are formed in the same gradient zone but gave an independent fault $\left(\mathrm{F}_{4}\right)$. It is observed that these lineaments represent the strike-slip Kolmani (graben) fault $\left(\mathrm{F}_{4}\right)$. The $\mathrm{L}_{5} \rightarrow \mathrm{L}_{6}, \mathrm{~L}_{7} \rightarrow \mathrm{L}_{8}$ and $\mathrm{L}_{7} \rightarrow \mathrm{L}_{14}$ lineaments can be considered as a double fault system $\left(\mathrm{F}_{5}\right.$ and $\left.\mathrm{F}_{6}\right)$ oriented in the SE-NE and SE-NW direction in the gradient zone. $\mathrm{L}_{12} \rightarrow \mathrm{L}_{13}$ Lineaments produced the fault system $\left(\mathrm{F}_{8}\right)$. The lineaments $\mathrm{L}_{9} \rightarrow \mathrm{L}_{11}$ which exist in a shear zone, are compatible with the buried fault and the two lineaments created one fault system $\left(\mathrm{F}_{10}\right)$.They identified fault traces named $\mathrm{L}_{1} \rightarrow \mathrm{L}_{9}$ and are shown in Fig. 5 as straight lines. The results of the SHD tectonic map shows that our proposed model is able to detect the minor faults within the study area. In the southwestern part of the study area, several minor lineaments which are clear on the tectonic map are shown on the map obtained by this proposed model. The relationship between these lineaments and faults can be corroborated from the model of the cross sections shown in Fig. 8, $a-d$.

The modelled cross section (Fig. 8, a) shows the reverse fault that correlates with line 94D032 on which lies the faults $\mathrm{L}_{1}-\mathrm{L}_{4}$ respectively. The contact boundaries were established by faults and this corroborates the model results in Fig. 8, a. Similarly, the Kolmani graben structure on the map (Fig. 6, 7) corroborates the model cross section in Fig. 8, $b$ which shows the block displacement. Fig. 8, $c, d$ model results shows the correlation of the contact boundaries in the NE Dukku subbasin with the maps in Fig. 5, 7 respectively.

The resulting set of lineaments/faults (Fig. 5,6 ) showed that most faults in the study area had sub-vertical dips. Interpreting the granite complex structural elements in the NW-SW part of the area, revealed that it was bounded to the north and southwest of the Gongola basin (upper Benue region) by main fractures interpreted as being normal faults. The SW-NE tending fault in the Alkaleri area was described as representing an intra-granitic fault. The gravity data for the northern part of the area was characterized by gravity lows, bounded by relatively steep gradients which could be interpreted as the result of mantle upwelling associated with high temperature; deep-seated basement structure associatedmelting had thus occurred in the lower crust [Abubakar et al., 2010]. Overall second horizontal derivative analysis results for gravity anomalies produced many features regarding trend and dip direction marking the faulted sedimentary and granitic basement boundary revealed a complex subsurface geological structure. These two areas were separated by a pronounced NE-SW fault recognized on both Bouguer, second horizontal derivative and isostatic residual gravity maps and was interpreted as being a basement fault. Low gravity anomaly expression was associated with granite intrusions while high gravity anomaly expression was associated with basement outcrop.

Discussion. The fault termination, displacement or interruption of otherwise long or continuous gravity anomalies seen in Fig. 5-7 represent significant geologic structural information which involves the exhibition of crustal formations typical of rift zone and deep-seated faults that may have related to trans-extensional movement. The 


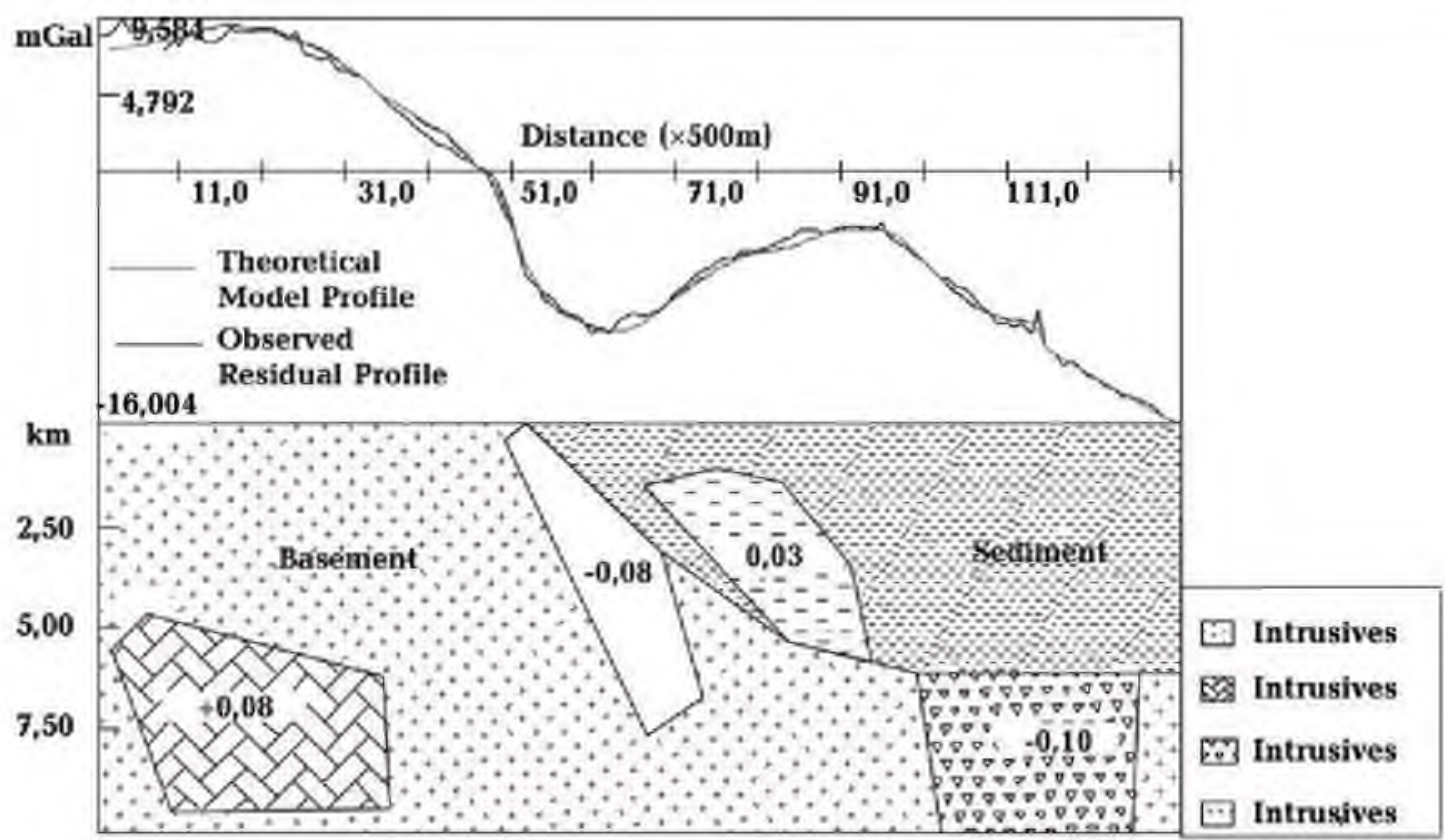

a

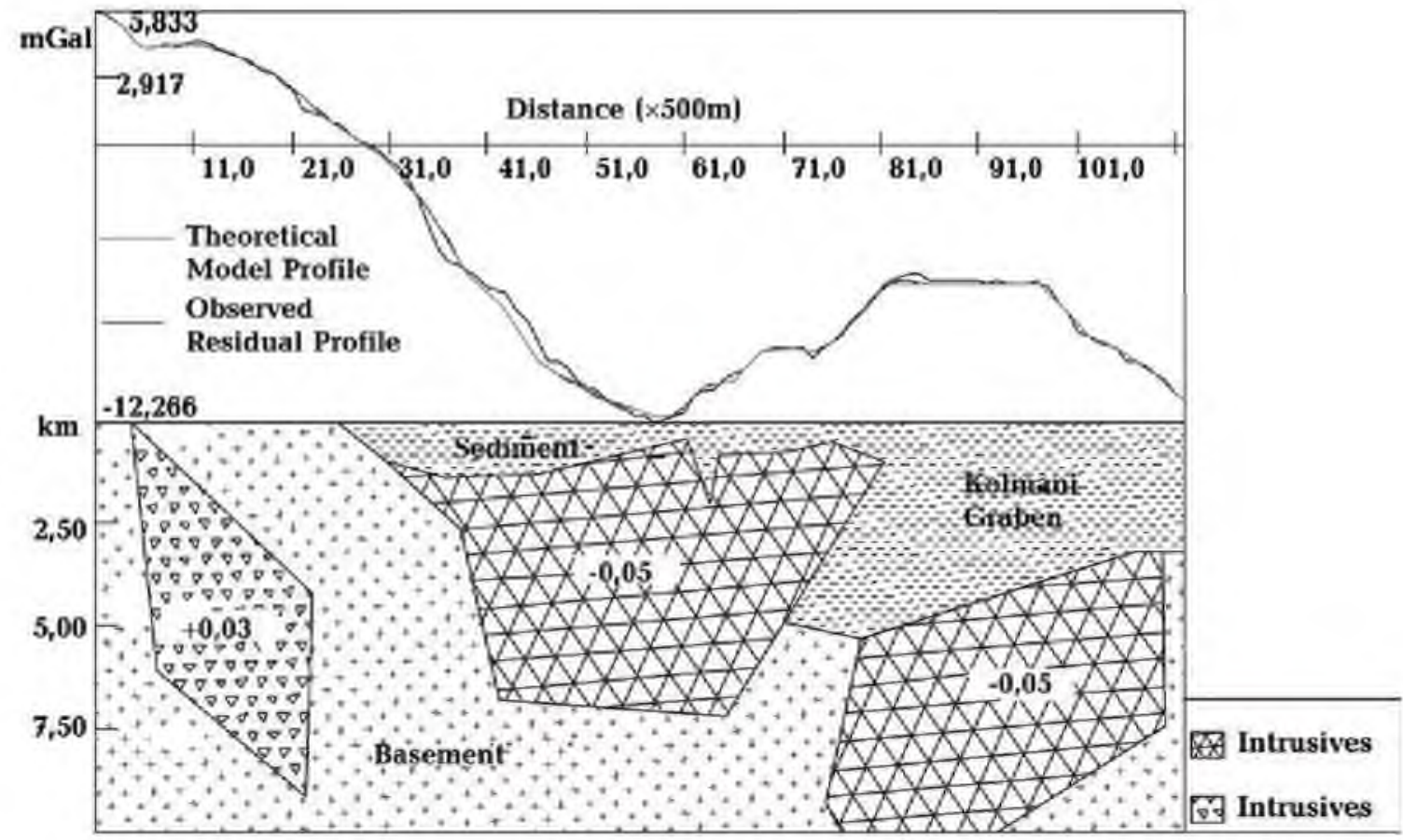

b

Fig. 8. Two-dimensional model showing: $a$ - reverse faults that deformed the lower part of the sedimentary faulting, sediment and intrabasement intrusive for Line 94D096; $d$ - block faulting, sediment and intra-base-

corroborants of the fault system are shown in Fig. 1, b. This resulted in the structurization of the original continental sedimentary fill. The W-E trending lineaments in Fig. 6, 7 are interpreted as fault (strike-slip) systems in the upper Benue Trough. The steep gradients evident in the gradient maps are reflection of sharp discontinuities or interfaces between basement blocks of contrasting properties, such as fault (see Fig. 8, c) basement shear 

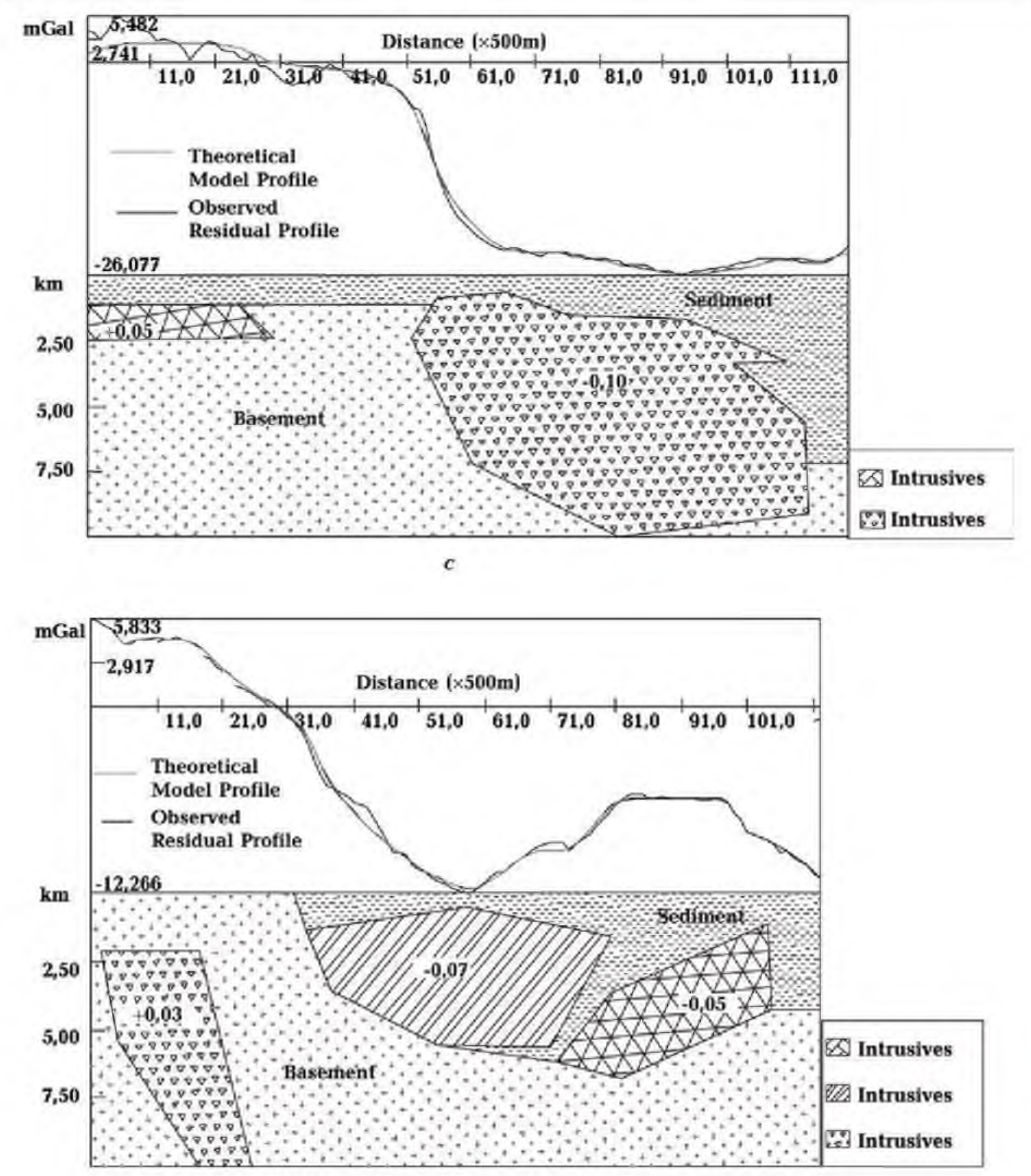

$\boldsymbol{d}$

sequence and basement intrusive for Line 94D032; $b$ - block faulting and intrusives for Line 94D048; $c$ - block ment intrusive for Line 94V120.

zones and intrusive contacts (see Fig. 8, d). Okiwelu et al. [2015] opined that the linear features on the SHD map represent lithological contacts, faults and fractures. The linear features were obtained from the maps corre- lated with the features in the cross-sectional gravity models. The NW-SE trend established in the Maastrichtian contains the following structural elements: the Kaltungo anticlinorium (NE-SW), the Bima anticlinorium (N-S) 
and the N-S Gulani syncline [Carter et al., 1963].

The second horizontal derivative map (see Fig. 7) clearly defines the edges of gravity anomalies and reveals some subtle N-S, NE and NW trending basement lineaments that correlate with geologic boundaries also shown in Fig. 1, $b$. The anomalies in the gradient and residual maps also corroborate in the lateral extent and amplitude and are pointers to spatial distribution of the anomalous mass in the sub-basins of Akko and Dukku and the graben structure of Kolmani in the SE mini-basin of the project area. The tectonic nature of the basement as shown in the gradient maps can therefore serve as an important tool for the prediction of the likely orientation of faults and fractures in the overlying Cretaceous sediments in the trough. These structures within the basement which influence the location of faulting within the sedimentary cover were reported by [Genik, 1993] and can also be visualized from the bounded fault block in the modelled cross-sections shown in Fig. 8, $a-d$.

The Basin Fault Structure. The surface subsidence of the developing rift basin enhances drainage and sedimentation into the rifts. These low density rift basin sediments generate a negative Bouguer anomaly (see Fig. 4). In corroborating the SHD, the isostatic residual anomaly map and the modelled cross sections, the tectonic nature of the basin is well defined. Figure 8a shows a modelled profile of line 94D032. It shows the presence of a reversed fault and intra-basement tectonic features. This corroborates with the Alkaleri-Akko fault: $F_{1}, F_{2}$ and $F_{3}$ respectively. The modelled cross section for line 94D048 (see Fig. $8, b$ ) shows the Kolmani graben structure within the Akko mini-basin of the basin. Akko fault represented by fault line $F_{3} / F_{4}$ and other mini faults within the graben. Fig. $8, b$ model correlates with the defined Kolmani graben in the SE as shown in Fig. 6. The large distinct density contact boundaries in the NE as shown on the SHD map is corroborated by the mass deposit shown in the modelled cross section of line 94D096 as shown in Fig. 8, c. Modelled cross section of line 94V120 as shown in Fig. 8, $d$ shows the faults and intrusives on that line. The fault shown on this model correlates with that shown in Fig. 6. It also shows fault $\mathrm{F}_{9}$ within the Darazo sub-basin; NW zone of the project area. These series of faults controlled the basin subsidence and the deposition of the Campano-Maastrichtian succession. The Benue Trough by these fault distribution, had a clear sinistral strike slip movement (see Fig. 1,b). The termination of this stage is indicated by a regional unconformity identified by Genik [1993]. The tectonic structures show that the basin was affected by an intense Santonian tectonic episode that resulted in folding and faulting of pre-Santonian sediments in a NE-SW direction. Benkhelil $[1982,1989]$ and Benkhelil and Robineau [1983] believed that the Gongola basin was mainly controlled by trending faults close to its eastern margin and this has been corroborated by the fault fabrics shown in the NE-SE part of the study area. These faults trending E-W (see Fig. 6) are the major structural feature that separates the Dukku, Akko and Finshare sub-basins where the older Bima-Yolde epicenter occurs (see Fig. 1, b).

Conclusions. In Gongola basin (upper Benue trough), the main structural features of the successions at the NE part are the NESW trending faults. Several reverse faults also occur with the SE-SW zone within the graben aiding deposition of the Campano-Maastrichtian succession within kolmani graben zone. The mini basins are interconnected by basement ridges and horst structures as shown in the modelled cross sections. The internal geometry of the upper Benue trough is controlled by the high-angle rift-stage faults, the NE-SW, E-W, N-S trending faults and intrabasement granitic intrusions. Furthermore, the subsidiary E-W and N-S trend faults attest to major but highly localized compression. This intense compression and the Kolmani graben formation suggests that wrenching played an important role in the tectonic evolution of the basin.

These results show that the proposed approach constitutes a useful tool to aid fault interpretation using gravity data. This approach 
is a useful tool for detecting deep faults, even in the presence of shallower near-surface features. This method, as applied to the location of edges of causative sources, is simple and easy to use and is a good approach for deter- mining vertical, or near vertical, faults.

Acknowledgements. We thank Shell Nigeria Exploration and Production Company (SNEPCO) for the release of the data used in this research.

\title{
Extraction of lineaments and faults using gravity second horizontal derivative data obtained using Fourier transform
}

\author{
E. E. Epuh ${ }^{1}$, E. O. Joshua ${ }^{2}, 2018$
}

\begin{abstract}
Linear anomalies are important in the interpretation of gravity data because they indicate some important structural features. Gravity anomalies obtained from horizontal derivatives generally reflect lineaments and faults or compositional changes which can describe structural trends of a region. This study involves the delineation of the Gongola basin structural trend based on the convolution between the Fourier kernel obtained from the second horizontal derivative (SHD) of the truncated horizontal plate model (THPM) and the gravity anomaly. The Fourier kernel for the second horizontal derivative was obtained through the application of Fourier transform over the expression of a Bouguer slab with exponential density contrast variation. The weighting density distribution is obtained through the determination of the mean depth perturbed by interfaces. The edges were identified by the closed maximum in the SHD gravity map. The results show that the region's Bouguer gravity is characterized by elongated SE-NE negative gravity anomaly corresponding to a collapsed structure associated with a granitic intrusion beneath the region, limited by the fault systems. This was clearly evident on an isostatic residual gravity map. The horizontal gradients of the Bouguer gravity anomaly data from the basin defined the edges, lineaments and faults structures very clearly. Major and minor lineaments derived from the SHD map were transposed on the isostatic residual map. These features led to the production of the structural map of the study area. The NE-SE and E-W trending lineaments were interpreted as fault (strike-slip wrench) systems. The steep gradients evident in the gradient maps are reflection of sharp discontinuities or interfaces between basement blocks of contrasting properties, such as: fault, basement shear zones and intrusive contacts. The tectonic information brought about by the distribution of the lineaments was corroborated by the $2 \mathrm{D}$ gravity model of the basin. These models and fault map will complement the selection of the promising areas for detailed hydrocarbon mapping.
\end{abstract}

Key words: second horizontal derivative, Fourier transform, Bouguer anomaly, lineament, faults.

\section{References}

Abubakar, Y. I, Umegu, M. N., \& Ojo, S. B. (2010). Evolution of Gongola Basin Upper Benue Trough Northeastern Nigeria. Asian Journal of Earth Sciences, 3(2), 62-72. doi: 10.3923/ ajes.2010.62.72.

Akande, S. O, Ojo, O. J, Erdtmann, B. D. \& Hetenyi, M. (1998). Paleoenvironments, Source Rock potential and thermal maturity of the Upper Benue Rift Basins, Nigeria. Implications for Hydrocarbon Exploration, Organic
Geochemistry, 29(1-3), 531-542. https://doi. org/10.1016/S0146-6380(98)00125-9.

Avbovbo, A. A, Ayoola, E. O. \& Osahon, G. A. (1986). Depositional and Structural Styles in the Chad basin of Northeastern Nigeria. AAPG Bulletin, 70(12), 1787-1798.

Aydogan, D. (2011). Extraction of Lineaments from gravity anomaly maps using that gradient calculation: Application to Central Anato- 
lia. Earth, Plants and Space, 63(8), 903-913. https://doi.org/10.5047/eps.2011.04.003.

Aydogan, D. (2007). Processing the Bouguer anomaly map of Biga and the surrounding area by the Cellular Neural Network: Application to the southwestern Marmara region. Earth, PIanets and Space, 59(4), 201-208. https://doi. org/10.1186/BF03353096.

Blakely, R. J., \& Simpson, R. W. (1986). Approximating edges of source bodies from magnetic or gravity anomalies. Geophysics, 5I(7), 14941498. https://doi.org/10.1190/1.1442197.

Benkhelil, J. (1982). The Origin and Evolution of the cretaceous Benue Trough (Nigeria). Journal of African Earth Science, 8(2-4), 251-282. https://doi.org/10.1016/S0899-5362(89)80028-4.

Benkhelil, J. \& Robineau, B. (1983). Is the Benue Trough a rift? Bulletin of Central Research and Exploration Production. Elf-Aquitaine, 7, $315-321$.

Benkhelil, J. (1989). The Origin and Evolution of the cretaceous Benue Trough (Nigeria). Journal of African Earth Science, 8(2-4), 251-282. https://doi.org/10.1016/S0899-5362(89)80028-4.

Boschetti, F. (2005). Improved edge detection and noise removal in gravity maps via the use of gravity gradients. Journal of Applied Geophysics, 57(3), 213-225. https://doi.org/10.1016/j. jappgeo.2004.12.001.

Boschetti, F., Hornby, P., \& Horowitz, F. G. (2001). Wavelet based inversion of gravity data. Exploration Geophysics, 32(1), 48-55.

Carter, J, D, Barber, W., Tait, A. E, Jones, J. P. (1963). The Geology of part of Adamawa, Bauchi and Borno Provinces in North Eastern Nigeria. Geological Survey of Nigeria Bulletin, 30 , 35- 53 .

Canny, J. (1986). A computational approach to edge detection. IEEE Transaction on Pattern Analysis and Machine Intelligence, PAMI-8(6), 679-698. doi: 10.1109/TPAMI.1986.4767851.

Chakravarthi, V. (2008). Gravity inversion of 2.5D faulted beds using depth-dependent density. Current Science, 95(11), 1618-1622.

Cooper, G. R. J., \& Cowan, D. R. (2006). Enhancing potential field data using filters based on the local phase. Computers \& Geosciences, 32(10), 1585-1591. https://doi.org/10.1016/j. cageo.2006.02.016.
Cooper, G. R. J., \& Cowan, D. R. (2008). Edge enhancement of potential-field data using normalized statistics. Geophysics, 73(3), H1- H4. https://doi.org/10.1190/1.2837309.

Cordell, L. (1973). Gravity Analysis Using an Exponential Density-Depth Function. Journal of Geophysics, 38(4), 684-690. https://doi. org/10.1190/1.1440367.

Cordell, L., \& Grauch, V. J. S. (1985). Mapping basement magnetization zones from aeromagnetic data in the San Juan Basin, New Mexico. In W. J. Hinze (Ed.), The utility of regional grav* ity and magnetic anomaly maps (pp. 181-197). Society of Exploration Geophysicists.

Fairhead, J. D., \& Binks, R. M. (1991). Differential Opening of the Central and South Atlantic Oceans and the Opening of the West Africa Rift System. Tectonophysics, 187(1-3), 191-203. https://doi.org/10.1016/0040-1951(91)90419-S.

Fairhead, J. D., Green, C. M., Masterton, S. M., \& Guiraud, R. (2013). The role that plate tectonics, inferred stress changes and stratigraphic unconformities have on the evolution of the West and Central African Rift System and the Atlantic continental margins. Tectonophysics, 594, 118-127. https://doi.org/10.1016/j. tecto.2013.03.021.

Fedi, M., \& Florio, G. (2001). Detection of potential fields source boundaries by enhanced horizontal derivative method. Geophysical Prospecting, 49(1), 40 - 58. doi: 10.1046/j.13652478.2001.00235.x.

Freeth, S. J. (1984). How many rifts are there in West Africa? Earth and Planetary Science Letters, 67(2), 219-227. https://doi. org/10.1016/0012-821X(84)90117-1.

Genik, G. J. (1993). Petroleum Geology of cretaceous-tertiary rift basins in Niger, Chad, and Central African Republic. American Association of Petroleum Geologists Bulletin, 77, 1405-1434.

Grant, N. K. (1971), South Atlantic, Benue Trough and Gulf of Guinea Cretaceous Tripple junction. Geolological Society of American Bulletin, 82(8), 2395-2298. https://doi. org/10.1130/0016-7606(1971)82[2295:SABTA G]2.0.CO;2.

Grant, F. S., \& West, G. F. (1987). Interpretation Theory in Applied Geophysics. Toronto: McGrawhill Book Company. 
Grauch, V. J. S., \& Cordell, L. (1987). Limitations of determining density or magnetic boundaries from the horizontal gradient of gravity or pseudogravity data. Geophysics, 52(1), 118-121. https://doi.org/10.1190/1.1442236.

Hornby, P., Boschetti, F., \& Horowitz, F. (1999). Analysis of potential field data in the wavelet domain, Geophysical Journal International, 137(1), 175-196. https://doi.org/10.1046/ j.1365-246x.1999.00788.x.

Hsu, S. K, Sibuet, J. C., \& Shyu, C. T. (1996). Highresolution detection of geologic boundaries from potential field anomalies: an enhanced analytic signal technique. Geophysics, 61(2), 373-386. https://doi,org/10,1190/1.1443966.

Lunscher, W. H. H. J. (1983). The asymptotic optimal frequency domain filter for edge detection. IEEE Transaction on Pattern Analysis and Machine Intelligence, PAMI-5(6), 678-679.

Klingele, E. E., Marson, I., \& Kahle, H.-G. (1991). Automatic interpretation of gravity gradient data in two dimension: Vertical gradient. Geophysical Prospecting, 39(3), 407-439. https:// doi.org/10.1111/j.1365-2478.1991.tb00319.x

Mallat, S., \& Zhong, S. (1992). Characterization of signals from multiscale edges. IEEE Transactions on Pattern Recognition and Machine Intelligence, 14(7), 710-732. doi: 10.1109/34.142909.

Marcotte, D. L., Hardwick, C. D., \& Nelson, J. B. (1992). Automated interpretation of horizontal magnetic gradient profile data. Geophysics, 57(2), 288-295. https://doi,org/10.1190/ 1.1443242 .

McGrath, P. H. (1991). Dip and depth extent of density boundaries using horizontal derivatives of upward continued gravity data. Geophysics, 56(10), 1533-1542. https://doi. org/10.1190/1.1442964.

Modestino, J. W., \& Fries, R. W. (1977). Edge detection in noisy images using recursive digital filter. Computer Graphics and Image Processing, 6(5), 409-433. https://doi.org/10.1016/ S0146-664X(77)80020-8.

Moreau, F., Gibert, D., Holschneider, M., \& Saracco, G. (1997). Wavelet analysis of potential fields. Inverse Problems, 13, 165-78.

Obaje, N. G. (2009). Geology and mineral resources of Nigeria. S. Bhattacharji, H. J. Neugebauer, J. Reitner, K. Stuwe (Eds.) Springer-Verlag Ber- lin Heidelberg. doi: 10.1007/978-3-540-92685-6.

Obaje, N. G, Attah, D. O., Opeloye, S. A, \& Moumouni, A. (2006). Geochemical Evaluation of the Hydrocarbon Prospects of Sedimentary Basins in Northern Nigeria. Geochemical Journal, 40(3), 227-243. https://doi.org/10.2343/ geochemj.40.227.

Obaje, N. G. (1994). Coal Petrography, microfossils and paleoenvironments of Cretaceous Coal measures in the middle Bebue Trough of Nigeria. Tuebingen Univ. (Germany).

Ofodile, M. E. (1976). The Geology of the Middle Benue, Nigeria. Publications from the Palaeontological Institution of the University of Uppsala, 4, 1-166.

Okiwelu, A. A., Okwueze, E. E., Akpan, P. O., \& Ude, I. A. (2015). Basin Framework and Basement Structuring of Lower Benue Trough, West Africa based on Regional Magnetic Field Data: Tectonic and Hydrocarbon Implications. Earth Science Research, 4(1), 1-20. doi: 10.5539/esr. v4n1p1.

Olugbemiro, R. O., Ligouis, B., \&Abaa, S. I. (1997). The Cretaceous Series in the Chad basin, NE Nigeria: Source Rock Potential and Thermal Maturity. Journal of Petroleum Geology, 20(1), 5168. https://doi.org/10.1111/j.1747-5457.1997. tb00755.x

Ologun, J. A., Ogezi, A. E., Ogunmola, J. K., \& Alaga, A. T. (2008). The application of remote sensing and GIS techniques in evaluating airborne radiometric anomaly around Wamba Nassarawa Egon area, North Central Nigeria. Niger, J. Space Res., 5, 95-114.

Osazuwa, I. B., Ajakaiye, D. E., \& Verheijen, P. J. T. (1981). Analysis of the structure of part of the Upper Benue Rift Valley on the basis of new geophysical data. Earth Evolution Sciences, (2), 126-135.

Petters, S. W. (1978). Stratigraphic evolution of the Benue Trough and its implications for the Upper Cretaceous paleogeography of West Africa. The Journal of Geology, 86(3), 311-322. https:// doi.org/10.1086/649693.

Petters, S, W. (1982). Central West African Cretaceous-Tertiary benthic foraminifera and stratigraphy. Palaeontographica Abteilung, $179,1-104$.

Petters, S. W., \& Ekweozor, C. M. (1982). Petroleum Geology of the Benue trough and south- 
eastern Chad basin, Nigeria. AAPG Bulletin, $66,1141-1149$.

Rao, D. A., Babu, H. V., \& Narayan, P. V. (1981). Interpretation of magnetic anomalies due to dikes: The complex gradient method. Geophy sics, 46(11), 1572-1578. https://doi.org/10.1190/ 1.1441164 .

Reid, A. B., Allsop, J. M., Granser, H., Millett, A. J., \& Somerton, I. W. (1990). Magnetic interpretation in three dimensions using Euler deconvolution. Geophysics, 55(1), 80-91. https://doi. org/10.1190/1.1442774.

Roest, W. R,, Verhoef, J., \& Pilkington, M. (1992). Magnetic interpretation using the 3-D analytic signal. Geophysics, 57(1), 116-125. https://doi. org/10.1190/1.1443174.

Shanmugam, K. S., Dickey, F. M. \& Green, J. A. (1979). An optimal frequency domain filter for edge detection in digital pictures. IEEE Transaction on Pattern Analysis and Machine Intelligence, PAMI-1(1), 37 - 49. doi: 10.1109/ TPAMI.1979.4766874.

Shen, J., \& Castan, C. (1986). An optimal linear op- erator for edge detection. Proceeding Conference on Vision and Pattern Recognition (CUPR) (pp. 109-114).

Trompat, H., Boschetti, F., \& Hornby, P. (2003). Improved downward continuation of potentíal field data. Exploration Geophysics, 34(4), 249-256. https://doi.org/10.1071/EG03249.

Tukur, A., Samaila, N. K., Grimes, S. T., Kariya, I, I., \& Chaanda, M. S. (2015). Two member subdivision of the Bima sandstone, Upper Benue trough, Nigeria: based on sedimentological data. Journal of African Earth Science, 104, 104-158. https://doi.org/10.1016/j.jafrearsci.2014.10.015.

Zeng, H., Zhang, Q., \& Liu, J. (1994). Location of secondary faults from cross-correlation of the second vertical derivative of gravity anomalies. Geophysical Prospecting, 42(8), 841-854. doi: 10.1111/j.1365-2478.1994.tb00244.x.

Zhang, H., Liu, T., \& Yang, Y.-S. (2011). Calculation of gravity and magnetic source boundaries based on anisotropy normalized variance. Chinese Journal of Geophysics, 54(4), 560-567. https://doi.org/10.1002/cjg2.1638. 